\title{
Histo-morphological lesions of gall bladder
}

\author{
P. Siva Kumar ${ }^{1}$, R. Swarupa Rani ${ }^{2, *}$, R. Sasidhar Raju ${ }^{3}$, K. Damayanthi ${ }^{4}$, M. Janaki ${ }^{5}$ \\ ${ }^{\mathbf{1}}$ Assistant Professor, ${ }^{2}$ Associate Professor, ${ }^{3,4}$ Post Graduate, ${ }^{5}$ Professor and HOD, Dept. of Pathology, Santhiram Medical \\ College, Kurnool, Andhra Pradesh, India
}

*Corresponding Author:

Email: swaruparaniragi@gmail.com

\begin{abstract}
Introduction: Gall stones are the commonest gall bladder lesions with an incidence of 10 to $20 \%$ of the world population. Biliary colic is common presenting symptom in majority of the lesions. It may be asymptomatic and incidental. Histological examination of cholecystectomy reveals the type of lesions.

Objective: To study the spectrum of gall bladder diseases. To study the lesion age and sex wise.

Materials and Methods: An analysis of 208 cholecystectomy specimens were done from 2014-2017.

Results: Cholelithiasis was more common in women, in age group of 40-50yrs. Pigmented stones were more common. Histopathologically the most common lesion was chronic calculus cholecystitis (102 cases), cholelithiasis, (40 cases) followed by Empyema (13 cases) and adenocarcinoma (04 cases) as incidental lesions.

Conclusion: Inflammatory lesions were common in gall bladder. Most common disease was chronic cholecystitis in women between 40-50yrs age, presented as abdominal colic. Pigmented stones were the most common etiology of chronic cholecystitis Malignancy of the gall bladder is rare and incidental.
\end{abstract}

Keywords: Gall bladder lesions, Gall stones, Chronic cholecystitis, Carcinoma.

\section{Introduction}

Gall stones are quite prevalent in most western countries. In United States, autopsy series have shown gall stones in $20 \%$ of women and $8 \%$ of men over the age of 40 (Kasper et al 2005). ${ }^{1-3}$ The non neoplastic lesions are more common than the neoplastic lesions. Among the non neoplastic lesions acute cholecystitis, calculous and acalculous cholecystitis, chronic cholecystitis, xantho granulomatous cholecystitis and Empyema of the gall bladder were noted.

Acute inflammation of gallbladder wall usually follow obstruction of the cystic duct by a stone. Three factors-mechanical, chemical and bacterial inflammation play a role in $50-80 \%$ of patients. The organisms frequently involves include-Escherichia coli, Klebsiella, Streptococcus and clostridium spp. The usual symptoms of acute and chronic cholecystitis are low grade fever, biliarycolic, nausea, vomitings and mild jaundice. ${ }^{4,5}$ Majority of patients with gallstones will have asymptomatic disease, diagnosis incidentally by imaging (U/S), CT or MRI for other health problems (Michael et al 2017). ${ }^{6-8}$ Cholecystectomy is the treatment of choice for all gallbladder lesions, irrespective of their nature or underlying disease process (Maulik et al 2014). ${ }^{3}$ Histopathological examination is the gold standard diagnostic modality for the diagnosis of both non malignant and malignant lesions.

\section{Aims and Objectives}

1. To study the incidence of various lesions, both non neoplastic and neoplastic lesions of gall bladder.

2. To study the age, sex wise incidence of the lesions.

3. To study the clinicopathological incidence of the gallbladder lesions.

\section{Materials and Methods}

The prospective study was done at Shantiram Medical College, Nandyal, Kurnool from January 2014 to December 2017 (3yrs). During the above period cholecystectomy specimens received in and around Nandyal were included in the present study. The detailed history regarding age, sex, clinical features, symptoms, and radiological findings were collected from the hospital records. The cholecystectomy specimens were fixed in $10 \%$ formalin. Surgical grossing, processing was done. Histopathological examination of the H\&E stained sections were done for evaluation of lesions. Ethical committee clearance was taken before the start of the study.

\section{Results}

In the 3 year period, total 208 cholecystectomies were analysed. All the patients presented with right hypochondrial pain, associated with fever and vomitings in 12 cases. Anorexia, fever and vague abdominal discomfort in 4 cases. In the present study chronic calculous cholecystitis was the most common lesion (102 cases) followed by chronic cholecystitis (40 cases) and acute cholecystitis ( 25 cases). All the lesions were noted in the age range of 10-70yrs and most commonly found in $4^{\text {th }}-5^{\text {th }}$ decade. Male to female ratio was 1:3. Pigmented stones (112 cases) were more commonly noted followed by cholesterol (10 cases) and mixed stones (5 cases) (Table 1-3).

On gross examination, the size of the stones varied from 0.5 to $1 \mathrm{~cm}$ and black to yellow in colour (Fig. 1). Gall stones more commonly noted in females of 40$50 \mathrm{yrs}$ age group. Most common risk factor among the females was obesity followed by diabetes mellitus and 
pregnancy. In acute and chronic calculus cholecystitis, grossly gallbladder was enlarged. Cut section revealed pigmented stones. Histology revealed normal/hyperplastic mucosa, acute and chronic inflammatory infiltrate in muscularis mucosae. In chronic calculus cholecystitis gall bladder was with firm fibrotic walls, atrophic and shrunken (40 cases). Microscopy revealed flattened mucosa and chronic inflammatory infiltrate and fibrosis. Gall bladder malignancy (adenocarcinoma) noted in females of 60$70 y r$ age group. Grossly gall bladder enlarged, showed fungating fragile, mass attached to fundus. Microscopy showed mucosal glands lined by row of cuboidal cells with hyperchromatic nucleus and moderate to scanty cytoplasm, mitotic figures, cells arranged as glandular pattern with secretions in the lumen (Fig. 2-4).

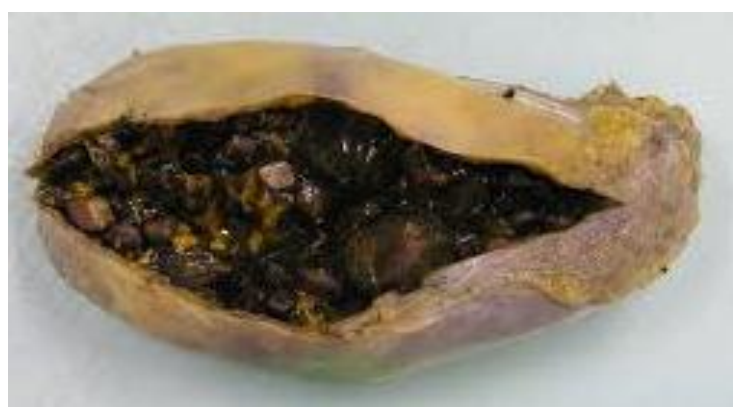

Fig. 1: Gross: gall stones

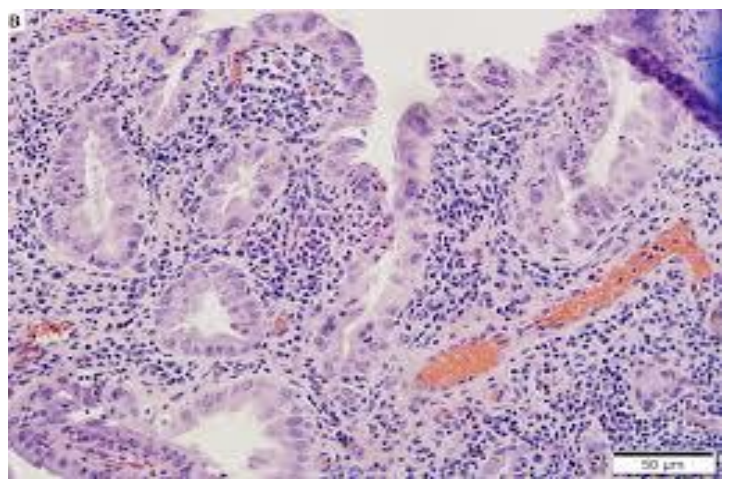

Fig. 2 Chronic cholecystitis - lymphoplasmocytic infiltrate low power, 10x

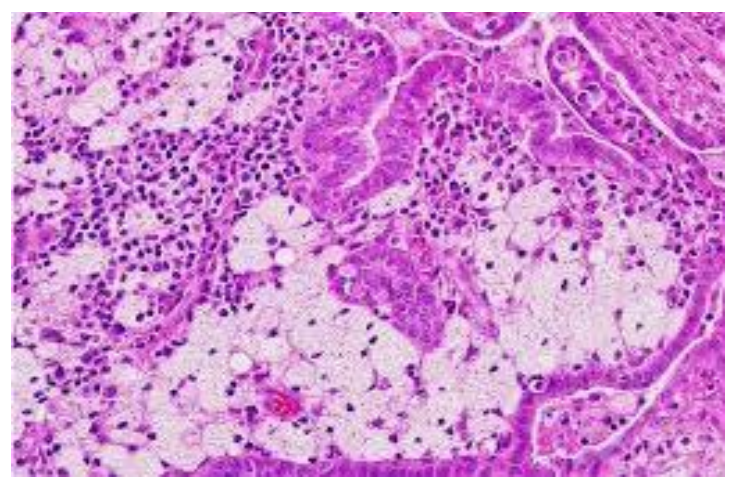

Fig. 3: Xanthogranulomatous cholecystitis - foamy macrophages and giant cells -high power $40 \mathrm{x}$

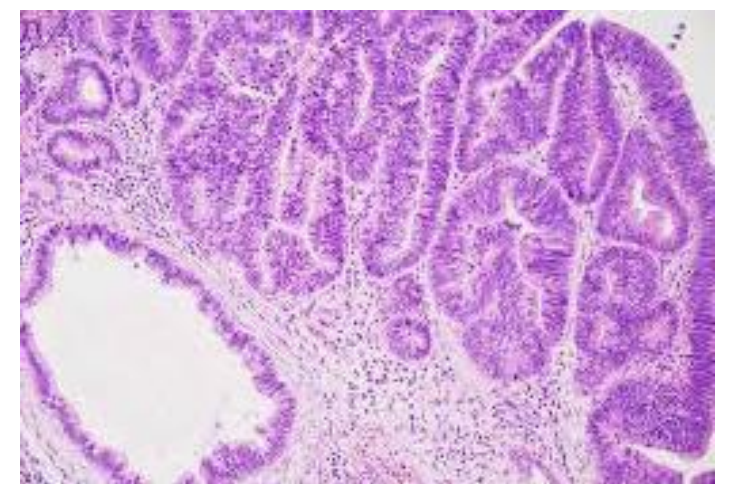

Fig. 4: Well differentiated adenocarcinoma -low power view $10 x$

Table 1: Incidence of lesions gall bladder

\begin{tabular}{|l|c|c|}
\hline \multicolumn{1}{|c|}{ Lesion } & No. of cases & Percentage \\
\hline Acute cholecystitis & 10 & $4.8 \%$ \\
\hline Acute calculus cholecystitis & 25 & $12.01 \%$ \\
\hline Chronic cholecystitis & 40 & $19.2 \%$ \\
\hline chronic calculus cholecystitis & 102 & $49 \%$ \\
\hline Empyema & 13 & $6.25 \%$ \\
\hline Acute on chronic cholecystitis & 10 & $4.8 \%$ \\
\hline $\begin{array}{l}\text { Xanthogranulomatous } \\
\text { cholecystitis }\end{array}$ & 4 & $1.92 \%$ \\
\hline Adenocarcinoma & 4 & $1.92 \%$ \\
\hline Total & 208 & $100 \%$ \\
\hline
\end{tabular}


Table 2: Age and gender wise distribution of gall bladder lesions

\begin{tabular}{|c|c|c|c|c|c|c|c|c|c|c|c|c|c|c|c|}
\hline \multirow[t]{2}{*}{ Lesion } & \multicolumn{2}{|c|}{$10-20$} & \multicolumn{2}{|c|}{$20-30$} & \multicolumn{2}{|c|}{$30-40$} & \multicolumn{2}{|c|}{$40-50$} & \multicolumn{2}{|c|}{$50-60$} & \multicolumn{2}{|c|}{$60-70$} & \multicolumn{3}{|c|}{ Total } \\
\hline & $\mathrm{M}$ & $\mathrm{F}$ & $\mathrm{M}$ & $\mathrm{F}$ & M & $\mathrm{F}$ & M & $\mathrm{F}$ & M & $\mathrm{F}$ & M & $\mathrm{F}$ & M & $\mathrm{F}$ & \\
\hline Acute cholecystitis & & & & & & 5 & 1 & 3 & 1 & & & & 2 & 8 & 10 \\
\hline Acute calculus cholecystitis & & & & & 2 & 8 & 1 & 7 & 1 & 6 & & & 4 & 21 & 25 \\
\hline Chronic cholecystitis & & & & & 1 & 11 & 3 & 16 & 3 & 4 & 2 & & 9 & 31 & 40 \\
\hline chronic calculus cholecystitis & & & 1 & 22 & 1 & 24 & 2 & 46 & 2 & 2 & 2 & & 8 & 94 & 102 \\
\hline Empyema & & & & & & 1 & 2 & 6 & 4 & & & & 6 & 7 & 13 \\
\hline Acute on chronic cholecystitis & & & & & & & 2 & 8 & & & & & 2 & 8 & 10 \\
\hline Xanthogranulomatous & & & & & & & 2 & & 1 & 1 & & & 1 & 3 & 4 \\
\hline Adeno carcinoma & & & & & & & & & & & 1 & 3 & 1 & 3 & 4 \\
\hline
\end{tabular}

Table 3: Clinical presentation of gall bladder lesion

\begin{tabular}{|l|c|c|c|c|c|c|c|c|}
\hline S. No & Lesion & Fever & $\begin{array}{c}\text { Biliary } \\
\text { colic }\end{array}$ & $\begin{array}{c}\text { Nausea } \\
\text { Vomitings }\end{array}$ & Jaundice & $\begin{array}{c}\text { Vague } \\
\text { abd pain }\end{array}$ & $\begin{array}{c}\text { Palpable } \\
\text { mass }\end{array}$ & Asymptomatic \\
\hline 1 & Acute cholecystitis & - & + & + & - & - & - & - \\
\hline 2 & $\begin{array}{c}\text { Acute calculus } \\
\text { cholecystitis }\end{array}$ & - & + & + & - & - & - & - \\
\hline 3 & Chronic cholecystitis & - & + & - & - & + & - & + \\
\hline 4 & $\begin{array}{c}\text { chronic calculus } \\
\text { cholecystitis }\end{array}$ & - & + & - & + & + & - & - \\
\hline 5 & Empyema & + & + & + & + & & - & - \\
\hline 6 & $\begin{array}{c}\text { Acute on chronic } \\
\text { cholecystitis }\end{array}$ & + & + & - & - & + & - & - \\
\hline 7 & Xanthogranulomatous & + & + & + & + & - & - & - \\
\hline 8 & Adeno carcinoma & - & + & - & - & + & + & - \\
\hline
\end{tabular}

\section{Discussion}

Cholecystitis refers to a group of disorders with varying clinical, pathogenic and pathological characteristics. The type of inflammatory cells infiltrate confirms the diagnosis (Devi Beena et al 2017). ${ }^{4}$

Out of 208 cases 204 cases were inflammatory and 4 cases were neoplastic lesions. Among the inflammatory lesions most common were chronic calculus cholecystitis (102 cases) and less common were xanthogranulomatous cholecystitis (04 cases).

Out of 208 cases, 34 cases were in males and 174 cases were in females with M:F ratio of 1:3.Our study correlated with Narendra et al $2015^{5}$, Selvi et al $2011^{9}$ and Memon et al 2011. ${ }^{7}$ In the present study chronic calculus cholecystitis is the most common lesion and correlated with Maulik et al 2014 (50\%). ${ }^{3}$

In the present study Neoplastic lesions were noted in $6^{\text {th }}$ to $7^{\text {th }}$ decades of life our study correlated with Memon et al 2005 and Maulik et al 2014. ${ }^{3}$ In present study maximum cases noted in females. Our study correlated with Sonam Mahana et al 2013, ${ }^{8}$ R. Thamil Selvi et al 2012, ${ }^{6}$ SK Mathur et al $2012^{10}$ and Khanna et al 2006. ${ }^{12}$ Sonam Mahana et al documented that the frequency of gall stones increases with age after 40yrs and common in older individuals and more in females. ${ }^{8}$ Female sex hormones influence hepatic bile secretion and gall bladder function.

In the present study majority of the patients presented with Right hypochondrial pain followed by fever and vomitings, study correlated with Devi Beena et al $2017,{ }^{4}$ Narendra et al $2015^{5}$ Naqvi et al $2005^{11}$ and Siddhiqui et al 2013. ${ }^{13}$ Gall stones are the major causes of mortality. They cause various lesions like acute cholecystitis, chronic cholecystitis and carcinoma of gall bladder. In the present study cholelithiasis noted in 127 cases and in 71 cases are acalculous cholecystitis. In the present study pigment stones were predominant (112 cases), Cholesterol stones in (10 cases) and (5 cases) with mixed stones. Our study was similar with the study of Devi Beena et al $2017^{4}$ and Selvi et al $2011 .{ }^{9}$

Goyal et al 2014 documented that mixed stones were predominant in $(68 \%) .{ }^{14}$ Our study differs from Goyal et al study (3.9\%). In our study microscopy revealed normal wall $(50 \%)$, mucosa $(64 \%)$, erosion of mucosa and denudation (17\%) hyperplastic mucosa $(1.9 \%)$ and fibrotic walls $(20 \%)$ and serosal congestion $(64 \%)$. Similar findings observed by Devi Beena et al 2017, ${ }^{4}$ Sumit et al $2013,{ }^{15}$ Baidya et al $2012^{16}$ and Khanna R et al 2006. ${ }^{12}$

In our study all the cases revealed predominantly lymphoplasmocytic infiltrate (75\%), mild lymphocytic infiltrate in 08 cases $(3.8 \%), 24$ cases with mixed inflammatory cells (12\%), foamy macrophages (8\%) and multinucleated giant cells in 04 cases $(1.9 \%)$. In the present study eosinophils in 2 cases $(1 \%)$, neutrophils in 10 cases $(4.8 \%)$ and in 2 cases (1\%) focal lymphoid aggregates. Study correlated with Devi Beena et al $2017 .^{4}$

In the present study ulceration of the mucosa and denudation in 35 cases (17\%) and fibrosis in 40 cases 
(20\%). Hyperplasia and metaplasia noted in 04 cases $(1.92 \%)$. Dysplasia and neoplasia noted in 04 cases $(1.92 \%)$. Our study correlated with Devi Beena et al 2017.4

\section{Conclusion}

Care must be taken to evaluate the cholecystectomy specimens, by both macroscopic and microscopic examination. The histopathological examination of all cholecystectomy specimens is mandatory to rule out the incidental malignancy. Histopathological examination is convenient and gold standard method for the diagnosis of various lesions of the gall bladder.

\section{References}

1. Harrison's internal Medicine volume II $16^{\text {th }}$ edition $\mathrm{Ch}$ 292 p 1880-1891.

2. Green field surgery - scientific principles and practice$6^{\text {th }}$ edition CH 61 p 996-1014.

3. Maulik K. Mehariya, Mahesh B. Patel, Sanjay V. Dhotre. Histopathological study of Gall bladder. Int J Res Med. 2014;3(4);96-99.

4. Devi Beena, Jayaprakash Shetty, Varsha Jose. Histopathological spectrum of diseases in Gall Bladder. National Journal of Lab Medicine. 2017;6(4):p006-p009.

5. Narendra GN, Gautam K. spectrum of benign gall bladder Diseases and their laparoscopic management: An experience of 100 patients. IJHRMLP. 2015;1(2): 25-31.

6. R. Thamil Selvi on 78 cholecystectomies. Tropical gastroenterology. 2012:33(1):39-44.

7. Memon W, Khanzada TW, Samad A, Kumar B Histopathological spectrum of gall bladder specimen after cholecystectomy. Pak J Med Sci. 2011;27:533-56.
8. Sonam Mahana, S.V. Poflee, N.P. Pande, A.V. Shrikhande, J Biosci Tech. 4(3),2013,519-524.

9. Selvi T, Sinha p, Subramaniam PM, Konapur PG, Prabha CV.A Clinicopathological study of cholecystitis with special reference to analysis of cholelithiasis. International Journal of Basic Medical Science. 2011;2(2):68-72.

10. SK Mathur et al on 330 cases Tropical Gastroenterology 2012:33(1):39-44.

11. Naqvi SVH Mangi IH, Dahri FJ Khaskheli QA, Akhund AA. Frequei cy of carcinoma gall bladder in patients with cholelithiasis Gomal. Journal of Medical Sciences. 2005;3(2).

12. Khanna R, Chansuria R, kumar M, Shukla HS. Histological changes in Ball bladder due to stone disease. Indian J Surg. 2006;68:20-04.

13. Siddhiqui FG, Memon AA, Abro AH Sasoli NA, Ahmad L Routin Histopathology of gall bladder after elective cholecystectomy for gall stones: waste of resources or a justified act? BMC Surgery. 2013;13:26.

14. Goyal S, Singla S, duhan A, Correlation between gallstones Characteristics and gall bladder mucosal changes: A retrospective study of 313 patients. Clinical cancer Investing J. 2014;3:157-61.

15. Sumit G. $\mathrm{C}$ changes in gall bladder mucosa associated with cholelithiasis. Int J Cur Res Rev. 2013;5(4):126-29.

16. Baidya R Sgel B, Baidya N L. Histopathological changes in gall bladder nucosa associated with cholelithiasis. Journal of Pathology 01 Nepal. 2012;2:224-25.

How to cite this article: Kumar PS, Rani RS, Raju RS, Damayanthi K, Janaki M. Histomorphological lesions of gall bladder. J Diagn Pathol Oncol. 2018;4(3):168-171. 